\title{
Instrumenty redukcji poziomu kongestii transportowej w ośrodkach miejskich
}

http://dx.doi.org/10.18778/8142-085-3.13

\author{
Andrzej Hanusik, Anna Woźnica \\ Katedra Logistyki Ekonomicznej \\ Uniwersytet Ekonomiczny w Katowicach
}

\section{Wstęp}

Jednym z najbardziej widocznych problemów komunikacyjnych występujących obecnie na drogach jest stale wzrastający poziom kongestii transportowej. Zjawisko to dotyka nie tylko duże zespoły miejskie, ale w mniejszym lub większym stopniu jest obecne praktycznie w każdym obszarze zamieszkałym. Jego negatywne skutki odczuwa coraz większa liczba mieszkańców na całym świecie, a straty materialne ponoszone $\mathrm{z}$ tego tytułu są znaczące. Niestety, bardzo często wypracowanie kompleksowych rozwiązań i metod walki z kongestią transportową leży poza zasięgiem finansowym i legislacyjnym samorządów lokalnych, tak więc poszukiwanie zaawansowanych i skutecznych narzędzi powinno stać się priorytetem oraz stanowić trzon polityki transportowej nie tylko dla administracji lokalnej, ale też musi być realizowane i koordynowane na szczeblu centralnym.

Wybór i opracowanie właściwych narzędzi ograniczania kongestii transportowej nie jest zadaniem łatwym. Wymaga gruntownej analizy aktualnej sytuacji panującej w mieście oraz skonfrontowania jej z możliwościami finansowymi budżetu, przestrzenną specyfiką danego obszaru, istniejącymi możliwościami technicznymi i technologicznymi, ale także oczekiwaniami lokalnej społeczności. Rozwiązania takie nie mogą odpowiadać tylko na doraźne potrzeby, muszą brać pod uwagę aspekt przyszłościowy. Zaznaczyć również trzeba, że ograniczanie poziomu kongestii transportowej w miastach nie może być celem samym w sobie, lecz powinno stać się częścią dużo szerszych działań prowadzonych w sposób ciągły, polegających na regularnym analizowaniu aktualnych potrzeb mieszkańców oraz rozwiązywaniu problemów występujących w mieście. Skuteczność nowych realizacji zależeć będzie nie tylko od liczby i skali wybranych rozwiązań, lecz przede wszystkim od stopnia ich współdziałania oraz wykorzystania w sposób zintegrowany. Takie podejście pozwala na wykorzystanie pełnych możliwości oferowanych przez każde z narzędzi i uzyskanie efektu synergii. 


\section{Istota zjawiska kongestii transportowej}

Termin kongestia sięga korzeniami do łacińskiego czasownika congero, który oznacza 'zbierać, gromadzić.' Źródło wyrazu nie jest jednak pochodzenia łacińskiego, gdyż w tym języku nie występuje jego odmiana rzeczownikowa. Słowo kongestia wywodzi się od angielskiego słowa congestion, co na język polski przetłumaczyć można jako „nagromadzenie krwi w jakiejś części ciała ${ }^{1 ”}$. Jest to więc termin stricte medyczny, przejęty przez nauki ekonomiczne, na gruncie których odnosi się do konsumpcji dóbr publicznych, w sytuacji gdy więcej niż jeden klient zainteresowany jest nabyciem danej usługi (Szołtysek, 2011: 48). Jak mogłoby wynikać z powyższej definicji, kongestia jest zjawiskiem powszechnym, występującym niezwykle często, praktycznie w każdym aspekcie funkcjonowania społeczeństwa. To jednak niepełny obraz, a zagadnienie jest o wiele bardziej złożone. Aby wystąpiła kongestia, spełnione muszą być trzy następujące warunki:

1) występowanie w określonym czasie większej liczby użytkowników danego dobra lub nabywców danej usługi,

2) zużycie przez konsumenta pewnych zasobów, np. wykorzystanie jakichś dóbr lub ubytek czasu,

3) bezpośrednia zależność pomiędzy czasem nabycia danego dobra a wolumenem zasobów na jego jednostkę (Tomanek, 2004: 60).

Istnienie powyższych warunków szczególnie widoczne jest w transporcie. Dało to początek nowemu, bardziej szczegółowemu terminowi, jakim jest kongestia transportowa (Tomanek, 2004). Występować może ona zarówno w sieci transportowej (na liniach transportowych, reprezentowanych przez drogę pokonywaną przez dany pojazd, w punktach transportowych, np. przystanki), jak i w samych środkach transportu (np. w autobusach) (Tomanek, 2004).

Wystąpienie kongestii transportowej zawsze prowadzić będzie do znaczących niedogodności w ruchu ulicznym. Pomimo że skutek kongestii zawsze będzie taki sam, to jej charakter może się znacząco różnić. Wyodrębnia się dwa rodzaje kongestii transportowej:

1) kongestia przypadkowa ( $\mathrm{z}$ ang. random congestion lub non-recurring congestion) - spowodowana jest zdarzeniami przypadkowymi, których wystąpienie ciężko lub nie sposób przewidzieć, np. złe warunki pogodowe, wypadki, wydarzenia wpływające na zwiększenie ruchu (np. protesty, koncerty);

2) kongestia cykliczna ( $\mathrm{z}$ ang. reccurring congestion) - związana jest $\mathrm{z}$ nadmiernym popytem transportowym, znacznie przekraczającym przepustowość drogi, występującym np. podczas godzin szczytu (Tomanek, 2004).

1 J. Maćkiewicz, Co znaczy wyraz „kongestia”, http://fil.ug.edu.pl/strona/15148/znaczy_wyraz_ kongestia [dostęp 11.04.2017]. 
Kongestia transportowa to zjawisko zdecydowanie niepożądane. Aby skutecznie ją ograniczać, konieczne jest poznanie jej istoty oraz czynników ją wywołujących. Przyczyny wystąpienia kongestii transportowej można podzielić na cztery główne kategorie:

1) wszystkie zdarzenia drogowe oddziałujące na płynność i szybkość przemieszczania się pojazdów, czyli:

- incydenty drogowe - sytuacje zakłócające prawidłowy ruch drogowy, wpływające na zmniejszenie wydajności pasów ruchu, czyli wszelkiego rodzaju kolizje, wypadki, ale i zdarzenia mające miejsce poza drogą, które rozpraszają uwagę kierowców,

- roboty drogowe - prace naprawcze lub konstrukcyjne podejmowane zarówno na drodze, jak i w jej okolicy, powodujące ograniczenie przepustowości jezdni poprzez wprowadzanie zwężeń lub ruchu wahadłowego, zmniejszenie liczby pasów ruchu lub całkowite zamknięcie drogi,

- warunki atmosferyczne - wszelkiego rodzaju opady, mgła, smog czy rażące słońce, powodujące pogorszenie widoczności lub zmniejszenie przyczepności pojazdu, co skutkuje znacznym zmniejszeniem prędkości poruszania się,

2) wzrastająca konieczność przemieszczania się, a więc:

- zmiany w intensywności przepływów - godziny szczytu związane z potrzebą dotarcia do miejsca pracy, a wobec tego znaczne zwiększenie się liczby samochodów na drogach skutkujące obniżeniem prędkości poruszania się pojazdów, pomimo braku wystąpienia konkretnych zdarzeń drogowych,

- wydarzenia nietypowe - wszelkie zdarzenia zachodzące incydentalnie, czyli koncerty, zawody sportowe, targi itp., znacząco wpływające na płynność i wielkość ruchu w pobliżu miejsca ich organizacji, jak również katastrofy naturalne czy ataki terrorystyczne uniemożliwiające lub utrudniające przemieszczanie się,

3) fizyczne właściwości dróg, to jest:

- instrumenty kontroli ruchu - brak synchronizacji sygnalizacji świetlnej z warunkami panującymi na drodze lub pozostawianie jej aktywnej w nocy,

- wydajność dróg - graniczna wielkość, jakiej mogą sprostać jezdnie, wynikająca m.in. z liczby pasów ruchu czy ich szerokości,

4) inne, to znaczy:

- efekt fali - niewielkie odległości pomiędzy pojazdami w sytuacji nagłego zmniejszenia prędkości ruchu przez jeden pojazd powodujące ograniczenie prędkości wielu innych samochodów,

- efekty wizualne - wszelkiego rodzaju czynniki rozpraszające, czyli obiekty występujące w okolicy drogi, prowadzące do obniżenia uwagi kierowcy, np. billboardy, 
- zaplanowane ograniczenia ruchu - przykładowo mogą to być punkty poboru opłat na autostradach,

- zmiany przebiegu jezdni - skrzyżowania, ostre podjazdy lub zakręty skutkujące zmniejszeniem prędkości poruszania się pojazdów,

- manewry użytkowników dróg - zmiany pasa powodujące zatrzymanie ruchu lub znaczne jego spowolnienie, np. przy zwężeniach, konieczność zmiany wielu pasów ruchu, poszukiwanie pasa o największym tempie przemieszczania się, próby omijania już istniejących zatorów poprzez poruszanie się wolnym pasem przeznaczonym do jazdy w innym kierunku oraz jego zmiana w ostatnim możliwym momencie, często powodująca zakorkowanie się również przejezdnego pasa (Tomanek, 2004: 52-60).

Pojawienie się kongestii transportowej wywołane może być wystąpieniem tylko jednego z powyższych czynników lub akumulacją wielu z nich (tzw. efekt negatywnej synergii). Przyczyny ją powodujące są od siebie ściśle zależne i wzajemnie się przenikają. Praktycznie niemożliwe jest więc bezbłędne przewidzenie miejsca $\mathrm{i}$ czasu wytworzenia się zatoru. Wynika to m.in. $\mathrm{z}$ różnego poziomu ruchu w poszczególnych dniach, jak i z nieregularności występowania zdarzeń drogowych. Możliwe jest tylko określenie miejsc podatnych na kongestię oraz takich, w których zawsze ona występuje.

Kongestia transportowa jest zjawiskiem niezaprzeczalnie negatywnym, wpływającym praktycznie na każdy aspekt życia współczesnego człowieka. Nie sposób również pominąć jej wpływu na środowisko naturalne. Nie jest to jednak zjawisko nowe, lecz towarzyszy naszej cywilizacji od początku jej istnienia. Ciągły rozwój oraz związana z nim zwiększona potrzeba mobilności dodatkowo je intensyfikuje. Ograniczanie tego problemu lub nawet całkowita jego niwelacja to aktualnie jedno z najważniejszych i najtrudniejszych zadań stojących przed społeczeństwem.

\section{Instrumenty przyczyniające się do obniżania poziomu kongestii transportowej}

Istnieje wiele narzędzi ograniczania kongestii transportowej. Nie oznacza to jednak, że wszystkie rozwiązania będą spełniać swoje zadanie w każdym mieście. Ich skuteczność zależeć będzie m.in. od przestrzennej charakterystyki miasta, stopnia zamożności jego mieszkańców czy zastosowania innych rozwiązań. Wszystkie z tych narzędzi można natomiast przypisać przynajmniej do jednej z trzech grup:
1) rozwiązania organizacyjne,
2) rozwiązania finansowe,
3) rozwiązania techniczne. 
Każda $\mathrm{z}$ tych grup jest ściśle związana z pozostałymi, a więc wytyczenie stałej granicy pomiędzy nimi jest praktycznie niemożliwe. Wiele narzędzi przyczyniających się do zmniejszenia zatłoczenia panującego na drogach zaliczyć można do więcej niż jednej kategorii. Cechą wspólną wszystkich narzędzi ograniczających kongestię transportową jest natomiast sukcesywne zmniejszanie liczby samochodów osobowych oraz ciężarowych na rzecz innych środków i sposobów przemieszczania się. Narzędzia te mogą mieć charakter pozytywny lub negatywny. Oddziaływanie pozytywne wiązać się będzie z aktywizacją mieszkańców, akcjami i kampaniami marketingowymi czy szeregiem korzyści (np. materialnych) dla osób postępujących w sposób zgodny z założeniami polityki transportowej miasta $^{2}$. Natomiast charakter negatywny tychże narzędzi to wszelkie obostrzenia dla ruchu samochodowego, zakazy czy dodatkowe opłaty.

Narzędzia organizacyjne w głównej mierze mają wpływać na zachowania komunikacyjne mieszkańców miast, a także na przedsiębiorców w nich działających. Powinny stanowić trzon działań podejmowanych przez podmioty kształtujące politykę transportową miasta, ponieważ to one stwarzają podstawy do dalszych działań. Narzędzia organizacyjne przyczyniające się do ograniczania zjawiska kongestii transportowej to $\mathrm{m}$. in.:

1) zwiększanie atrakcyjności transportu zbiorowego - priorytetem w działaniach władz miasta powinno być przeniesienie ciężaru $\mathrm{z}$ transportu prywatnego na publiczny. Służyć temu mogą rozmaite działania związane z promocją transportu miejskiego (reklamy, programy edukacyjne), jak również usprawnienia i udogodnienia zarówno na drogach, jak i w samych środkach komunikacji;

2) separacja ruchu rowerowego oraz systemy wypożyczania rowerów - stworzenie warunków do bezpiecznego poruszania się rowerami oraz możliwości ich wypożyczania powinno znacząco przyczynić się do zmniejszenia zatłoczenia na drogach. Stacja służąca do wypożyczania jednośladów zajmuje około 2-3 standardowych miejsc parkingowych dla samochodów i potrafi pomieścić do 10 rowerów. Obserwacje pokazują, że z jednego wypożyczonego roweru dziennie skorzystać może nawet 15 osób, co stwarza możliwość podróżowania nawet dla 150 użytkowników takiej stacji (Biała Księga Mobilności, 2015: 119);

3) system nocnych dostaw do sklepów - wiele dostaw jest wciąż realizowanych rano, często podczas trwania szczytu komunikacyjnego. Przyczynia się to zarówno do zwiększenia liczby samochodów przemieszczających się wtedy po ulicach, jak również do zablokowania niektórych pasów ruchu ${ }^{3}$.

2 CIVITAS. Cleaner and better transport in cities, Policy Advice Notes. Promowanie nowej kultury mobilności w miastach, s. 2-5, http://www.civitas.eu/sites/default/files/civitas_ii_policy_ advice_notes_08_promotion_and_education_pl.pdf [dostęp 12.04.2017].

3 Zablokowanie pasów ruchu z reguły wynika z braku miejsc postojowych dla samochodów dostarczających ładunki do sklepów. Konieczne jest więc wytyczenie takich miejsc, a czasem nawet osobnych pasów przeznaczonych tylko i wyłącznie na rozładunek, aby wyładowywane pojazdy nie utrudniały ruchu innym jego uczestnikom. 
Konieczne może okazać się wydanie odpowiednich regulacji prawnych wymuszających nocne dostawy. Prowadzenie zaopatrzenia w nocy nie będzie wpływać na tworzenie się zatorów komunikacyjnych, gdyż w tym okresie ruch jest minimalny;

4) kooperacja i konsolidacja dostaw - w praktyce każde przedsiębiorstwo korzysta z odrębnego, indywidualnego systemu dostaw. Często również zdarza się sytuacja, w której różni dostawcy dowożą towary do tego samego odbiorcy. Powoduje to znaczne zwiększenie liczby samochodów dostawczych na ulicach. Dodatkowo wiele ich przebiegów jest pustych lub z niepełnym załadunkiem. Dobrym rozwiązaniem jest zintegrowanie dostaw różnych przedsiębiorstw oraz konsolidacja ładunków przeznaczonych do jednego odbiorcy. Oprócz tego planowanie optymalnej trasy pomiędzy kilkoma punktami dostawy pozwoli zmniejszyć liczbę przejeżdżanych kilometrów, co nie pozostanie bez wpływu na środowisko. Rozwiązanie takie wymaga jednak stworzenia wspólnej platformy dla wszystkich zainteresowanych, a więc zarówno dla właścicieli sklepów czy punktów usługowych, jak i dla dostawców. Nie jest to zadanie proste, jednak jego realizacja umożliwia uzyskanie efektu synergii i znaczne ograniczenie liczby samochodów dostawczych poruszających się po ulicach miasta. Co więcej, dostawy towarów można połączyć z jednoczesnym odbiorem odpadów opakowaniowych, co dodatkowo zmniejszy liczbę wykonywanych kursów (Kauf, 2010: 41-44);

5) zmiana organizacji ruchu - ulice wcześniej dwukierunkowe zostają zamienione na jednokierunkowe, wprowadza się zakazy wjazdów (z reguły dla określonej grupy pojazdów) czy wykonywania pewnych manewrów. Nowe rozplanowanie ruchu oraz próba zoptymalizowania przepływów na istniejącej już sieci transportowej również potrafią zmniejszyć poziom występującej kongestii transportowej.

Narzędzia finansowe w dużej mierze opierają się na zniechęcaniu mieszkańców miasta do korzystania z prywatnych samochodów poprzez stosowanie różnego rodzaju opłat. Są to więc w głównej mierze narzędzia negatywnego oddziaływania na zachowania komunikacyjne. W grupie tej jednak znajdują się również instrumenty pozytywnego oddziaływania, które pozwalają uczestnikom ruchu na znaczne oszczędności (np. mniejsze wydatki na paliwo). Do grupy finansowego oddziaływania zaliczają się takie narzędzia, jak:

1) polityka parkingowa - w dzisiejszych czasach wiele centrów dużych miast (a więc obszarów występowania największej kongestii transportowej) charakteryzuje się przewagą popytu na miejsca parkingowe nad ich fizyczną ilością (Thiem i in., 2015: 39-41), a w szczególności zbyt małą pojemnością parkingową w dzień oraz nadmiarem miejsc postojowych w nocy (Polityka parkingowa miasta Płock..., s. 9). Stan taki generuje dodatkowy ruch uliczny powodowany przez osoby poszukujące miejsca do pozostawienia 
swojego pojazdu. Co więcej, samochody te poruszają się bardzo wolno, utrudniając ruch innym i powiększając przy tym kongestię transportową. Wprowadzenie restrykcyjnej polityki parkingowej zwiększa rotację pozostawianych pojazdów (skracając czas potrzebny na znalezienie wolnego miejsca parkingowego) oraz zniechęca mieszkańców do użytkowania samochodu osobowego;

2) opłaty za korzystanie z dróg - aby dodatkowo zniechęcić ludzi do użytkowania samochodów prywatnych, można wprowadzić na wybranych obszarach system poboru opłat wjazdowych. Jedną z głównych zalet tej koncepcji jest fakt, że nie wpływa ona tylko i wyłącznie na osoby pozostawiające swój samochód w centrum miasta (a więc głównie ludzi tam pracujących), lecz także na osoby tylko przez nie przejeżdżające. Co więcej, system ten może wymusić na mieszkańcach użytkowanie jedynie samochodów spełniających określone normy emisji spalin (np. Europejski Standard Emisji Spalin EURO 6) poprzez stosowanie systemu ulg dla samochodów ekologicznych (Innovative Demand Management Strategies..., s. 4);

3) preferencje dla Carpooling ${ }^{4}$ - idea carpoolingu polega na zapełnianiu samochodu, w celu maksymalnego jego wykorzystania. Średnie napełnienie samochodu w Warszawie (podobnie jak w innych miastach tak Polski, jak i Europy) wynosi 1,3 osoby/samochód ${ }^{5}$. Wspólne przejazdy niosą ze sobą same korzyści - zmniejszenie zatłoczenia na ulicach, podział kosztów związanych z zakupem paliwa oraz umożliwienie dojazdu do celu osobom nieposiadającym własnego środka lokomocji bez konieczności dokonywania wielokrotnych i uciążliwych przesiadek. Warunkiem koniecznym jest jednak posiadanie takiego samego celu podróży (ew. celu podróży leżącego na trasie przejazdu właściciela samochodu) oraz podróż w tym samym czasie. Ten drugi warunek jest trudniejszy do spełnienia, co nierzadko przyczynia się do niemożności skorzystania z tej koncepcji. Najpopularniejszymi serwisami oferującymi wspólne przejazdy są w Polsce BlaBlaCar oraz Jedziemy Razem, a w Europie Ridfinder 6 .

Narzędzia techniczne to $w$ głównej mierze rozbudowa i modernizacja infrastruktury transportowej oraz tworzenie Inteligentnego Systemu Transportowego. Zabiegi prowadzone $\mathrm{w}$ tym zakresie niejednokrotnie ściśle związane są z poprzed-

4 Carpooling zaliczyć można zarówno do narzędzi organizacyjnych, gdyż wiąże się on ze zmianami zachowań komunikacyjnych mieszkańców (większe zapełnienie poszczególnych pojazdów), jak i do grupy instrumentów finansowych pozytywnego oddziaływania, gdyż w znaczącym stopniu wpływa na zmniejszenie kosztów ponoszonych przez poszczególne osoby.

5 http://www.ztm.waw.pl/informacje.php?i=157\&c=98\&l=1 [dostęp13.04.2017].

6 Serwisy te są dostępne pod adresami:

- BlaBlaCar - https://www.blablacar.pl/

- Jedziemy Razem - http://www.jedziemyrazem.pl/

- Ridefinder - http://www.ridefinder.eu/. 
nimi grupami (np. system dynamicznej informacji pasażerskiej, który jest częścią Inteligentnego Systemu Transportowego, lub budowa buspasów, czyli rozbudowa już istniejącej infrastruktury), zaznaczyć jednak trzeba, że należą one do osobnej kategorii. Często również działania te nie przyczyniają się do spadku liczby samochodów poruszających się po drogach, lecz do optymalizacji ich przepływów. Przykładem może być inteligentnie sterowana sygnalizacja świetlna. Ciągły wzrost liczby pojazdów poruszających się po drogach wymusza budowanie coraz większej liczby sygnalizatorów świetlnych, a te bezpośrednio wpływają na obniżenie sprawności ruchu i powstawanie zatorów (Ziemska, 2014: 107). Dobrym rozwiązaniem jest lokowanie na skrzyżowaniach kamer monitorujących aktualny poziom ruchu. Za pomocą tych danych komputer odpowiednio steruje działaniem sygnalizacji świetlnej, zmniejszając czas oczekiwania na przejazd dla pasów bardziej zatłoczonych, co skutkuje zwiększeniem płynności ruchu. Nadaje on również priorytet przejazdu pojazdom komunikacji miejskiej. Innym przykładem rozwiązań Inteligentnego Systemu Transportowego są tablice informacyjne dla kierowców. Wyświetlają one informacje o korkach i wypadkach oraz sugerują objazd zalecanymi drogami ${ }^{7}$. Dodatkowo informacje o aktualnym ruchu dostępne są na stronach internetowych oraz $\mathrm{w}$ aplikacjach mobilnych ${ }^{8}$. Takie rozwiązania $\mathrm{w}$ sposób oczywisty zmniejszają poziom kongestii transportowej. Również rozbudowanie infrastruktury znacząco przyczynia się do usprawnienia ruchu. Tworzenie nowych przystanków autobusowych (a co za tym idzie nowych połączeń), jezdni samochodowych czy torowisk tramwajowych również wpłynie na zmniejszenie zatłoczenia na drogach. Często jednak ze względu na ścisłą zabudowę miasta takie rozwiązania nie są możliwe9. Ważnym aspektem jest również wyeliminowanie z miasta ruchu tranzytowego. Wiele samochodów tylko przejeżdża przez dane miasto, nie zatrzymując się w nim. Dzieje się tak głównie wtedy, gdy dany obszar leży na ważnych szlakach komunikacyjnych (np. TEN-T, czyli Transeuropejskiej Sieci Transportowej) lub gdy miasto nie posiada sieci obwodnic pozwalających samochodom na jego ominięcie. Kierowcy są więc zmuszeni do przejazdu przez miasto, alternatywna trasa bowiem wiązałaby się z nadłożeniem wielu kilometrów. Wpływa to negatywnie nie tylko na poziom kongestii transportowej, ale również na liczbę wypadków samochodowych, obniżenie jakości życia mieszkańców (wysoki poziom hałasu, zanieczyszczenie środowiska) oraz pogorszenie się stanu dróg.

7 Zarząd Dróg Miejskich i Komunikacji Publicznej w Bydgoszczy, O bydgoskim systemie ITS, http://www.zdmikp.bydgoszcz.pl/index.php/pl/inwestycje-i-projekty/2305-o-systemie-its [dostęp 13.04.2017].

8 Przykładem takiej interaktywnej strony internetowej udostępniającej informację o aktualnym stanie ruchu, jak i o całym systemie, jest strona ITS Bydgoszcz - zob. http://www.its.bydgoszcz.pl/.

9 W wielu miastach budynki ulokowane są bezpośrednio przy samej ulicy, co uniemożliwia dobudowę nowych pasów ruchu czy utworzenie linii tramwajowej. Co więcej, nie wszystkie ulice przystosowane są do poruszania się po nich dużych pojazdów komunikacji miejskiej, takich jak autobusy. 
Istnieje wiele narzędzi służących ograniczaniu kongestii transportowej. Nie każde $\mathrm{z}$ nich jednak nadaje się do zastosowania we wszystkich miastach. Przy ich implementacji należy wziąć pod uwagę specyfikę danego ośrodka miejskiego oraz jego przestrzenną charakterystykę. Niewłaściwie dobrane rozwiązanie nie tylko nie usunie problemu, ale może go zintensyfikować. Do władz należeć będzie ocena sytuacji panującej w mieście i taki dobór narzędzi ograniczających kongestię, które najlepiej wpasowywać się będą w specyfikę danego ośrodka miejskiego. Wybór instrumentów walki z zatłoczeniem panującym na drogach należy poprzedzić gruntowną analizą problemu, a sposób ich implementacji dokładnie rozplanować. Warto wzorować się na innych miastach, które z sukcesem wykorzystują już wiele istniejących narzędzi do walki z kongestią transportową.

\section{System ERP w Singapurze - studium przypadku}

Singapur to państwo-miasto, które własną państwowość uzyskało dopiero w roku 1965. Państwo to bardzo dynamicznie się rozwija. W ciągu 50 lat jego istnienia PKB per capita wzrósł z poziomu 516 dolarów amerykańskich (notowanych w pierwszych latach istnienia Singapuru) do wielkości 56284 dolarów w czasach obecnych (Singapur: pół wieku azjatyckiego cudu, 2015) (co daje łączny wzrost o prawie 11 000\%). Dodatkowo Singapur przoduje w liczących się światowych rankingach ekonomicznych - jest drugim krajem na świecie według kryterium wolności gospodarczej (Schwab, 2014: 12) oraz drugą najbardziej konkurencyjną gospodarką świata (Index of Economic Freedom, 2016). Tak znaczny wzrost ekonomiczny w naturalny sposób stymuluje rozwój transportu oraz potrzebę przemieszczania się mieszkańców, co nie pozostaje bez wpływu na poziom kongestii transportowej występującej w regionie. Sytuacja taka wymusiła na władzach wprowadzenie systemu ograniczającego ruch samochodów prywatnych w centrum miasta. Dobrym rozwiązaniem okazał się system elektronicznego poboru opłat - ERP (Electronic Road Pricing).

System poboru opłat znacząco może przyczynić się do ograniczenia zatłoczenia panującego na drogach. Zniechęca on mieszkańców do korzystania z transportu indywidualnego, przyczyniając się przy tym do wzrostu atrakcyjności transportu publicznego ${ }^{10}$. Dodatkowo jest to rozwiązanie o wiele bardziej neutralne niż całkowite wyłączenie z ruchu niektórych obszarów miejskich.

10 System ERP zwiększa atrakcyjność transportu publicznego zarówno w sposób bezpośredni, jak i pośredni. Opłaty za wjazd zazwyczaj przekraczają wysokością ceny biletów na transport 
Największym problemem może się okazać stworzenie skutecznego systemu poboru opłat oraz narzędzi kontroli ich wnoszenia. Najpopularniejszym rozwiązaniem są abonamenty wjazdowe lub karnety. Nie jest to jednak rozwiązanie idealne, gdyż wymaga powołania specjalnej jednostki zajmującej się kontrolą uiszczania opłat przez użytkowników dróg. Co prawda, można obowiązek ten przekazać w gestię służb porządkowych (takich jak policja czy straż miejska), skutkować to jednak będzie znacznym ograniczeniem ich efektywności w podstawowym obszarze zadań. Dobrym rozwiązaniem okazuje się system elektronicznego poboru opłat (ERP). Automatycznie pobiera on opłatę za wjazd oraz kontroluje, czy dany pojazd może ją uiścić. W przypadku nieodprowadzenia odpowiedniej kwoty numer rejestracyjny samochodu zostaje przekazany odpowiednim służbom, które następnie zajmują się ukaraniem kierowcy. Wymaga to jednak instalowania w samochodach urządzeń zintegrowanych z systemem. Sposób działania systemu ERP przedstawia rysunek 1.

Wprowadzenie systemu elektronicznego poboru opłat niesie ze sobą wiele korzyści. Pełni on swoistą rolę edukacyjną dla społeczności lokalnej, pokazując, jakie koszty są związane z użytkowaniem samochodu osobowego. Środki uzyskane z działalności systemu służą nie tylko do zapewnienia bezawaryjnego jego działania, lecz są także lokowane w istniejącą infrastrukturę transportową (np. remonty) (Innovative Demand...: 2). Zmniejsza się liczba samochodów na drogach, a co za tym idzie także czas przeznaczany przez użytkowników dróg na dojazdy (Road pricing. Necessity or nirvana?, 2012). Jedynym, aczkolwiek znaczącym minusem systemu jest konieczność posiadania specjalnego urządzenia w swoim samochodzie. Dla mieszkańców danego miasta nie będzie to duży problem, lecz dla osób sporadycznie korzystających z dróg obszaru objętego systemem ERP już tak. Pomimo posiadanych wad system elektronicznego poboru opłat jest bardzo dobrym narzędziem ograniczania kongestii transportowej. Jego wprowadzenie oraz bardzo restrykcyjna polityka transportowa, zmuszająca użytkowników prywatnych samochodów osobowych do posiadania specjalnej licencji wymagającej odnawiania co dziesięć lat oraz wnoszenia przy tym opłaty w wysokości od 60 tys. do 100 tys. dolarów singapurskich ${ }^{11}$ (stawki ustalane są regularnie przez odrębne przepisy) (Stępniak, 2015) przyniosły znaczne oszczędności czasu kierowców. W 2014 roku mieszkańcy Singapuru tracili około 31\% czasu więcej podczas poruszania się po mieście w dzień, 50\% więcej czasu podczas porannych godzin szczytu oraz $59 \%$ podczas szczytu wieczornego. Ogólna oszczędność czasu mieszkańców tego kraju w roku 2015, w porównaniu do roku poprzedniego, wynosiła około 126 godzin na jednego mieszkańca (Traffic congestion improved in Singapore in 2015: Report, 2016).

publiczny, co przyczynia się do wyboru innych sposobów przemieszczania się niż samochód osobowy. Jest to bezpośrednie oddziaływanie na atrakcyjność transportu publicznego. Pośrednimi efektami jest krótszy czas przejazdu autobusów, spowodowany mniejszym zatłoczeniem panującym na drogach.

11 Kurs dolara singapurskiego (SGD) na dzień 13.04 .2017 wynosił 2,85 złotych za jeden dolar singapurski. 

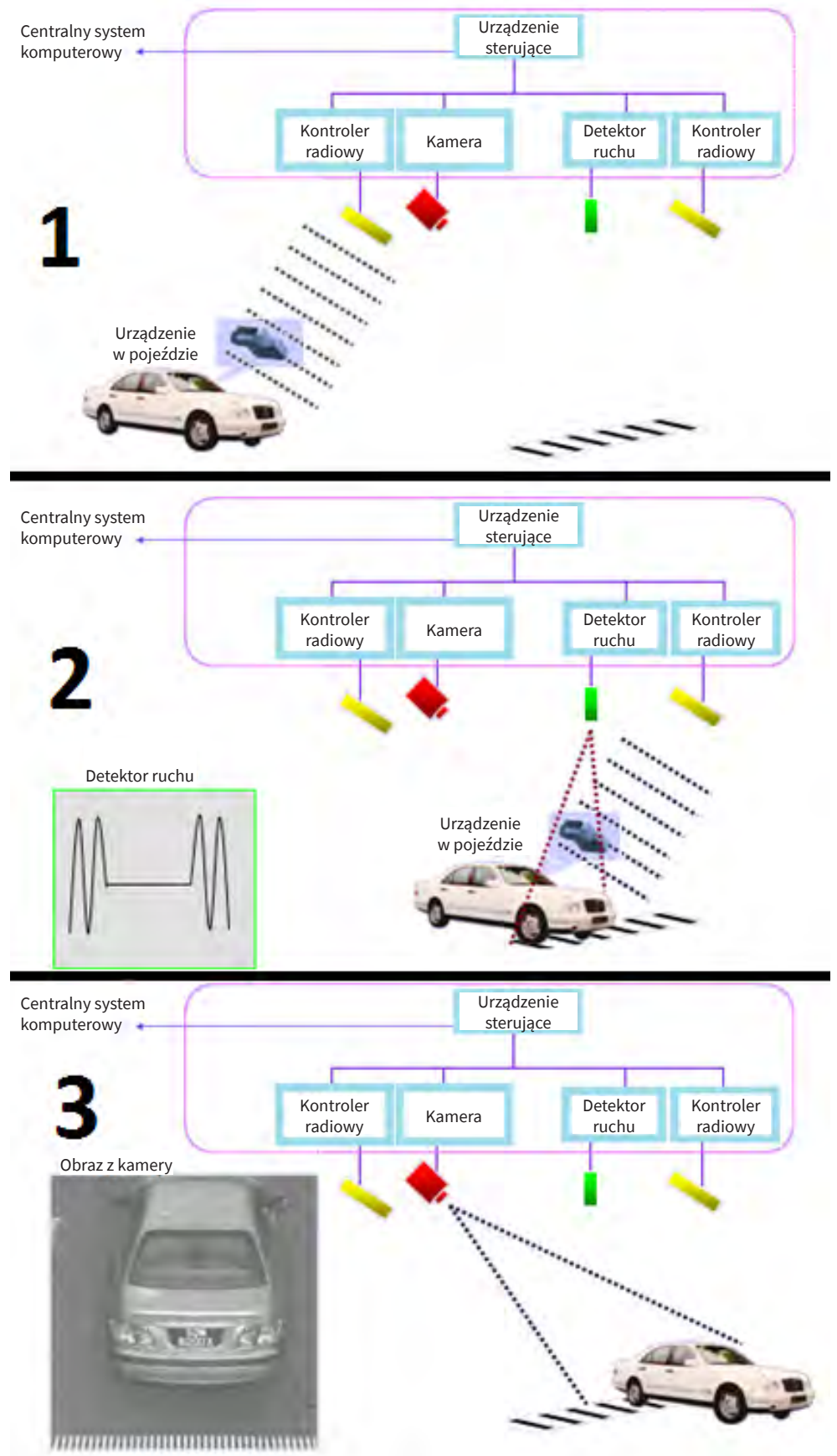

Rysunek 1. Sposób działania systemu ERP

Źródło: opracowanie własne na podstawie Menon, 2003: 10-12. 


\section{Projekt RegLog w Ratyzbonie - studium przypadku}

Ratyzbona to bawarskie miasto na prawach powiatu o populacji około 150 tysięcy ludności. Bardzo wąskie uliczki w obrębie ścisłego centrum miasta, związane ze średniowiecznym charakterem zabudowy, nie są w stanie obsłużyć w zadowalającym stopniu ruchu ulicznego. Co więcej, samo stare miasto zajmuje powierzchnię około $1 \mathrm{~km}^{2}$, a mieści się w nim około 500 małych sklepów oraz 200 innych niewielkich prywatnych przedsiębiorstw (TRAILBLAZER..., 2010: 3). Tak duże nagromadzenie punktów handlowo-gospodarczych na tak niewielkim obszarze, w połączeniu z niską przepustowością uliczek, doprowadziło do powstawania potężnych zatorów drogowych spowodowanych prowadzonymi dostawami. Ulice nie były w stanie obsłużyć tak dużej liczby samochodów dostawczych. Dodatkowo pojazd taki na czas wyładunku musiał się zatrzymać, blokując przy tym większą część ulicy.

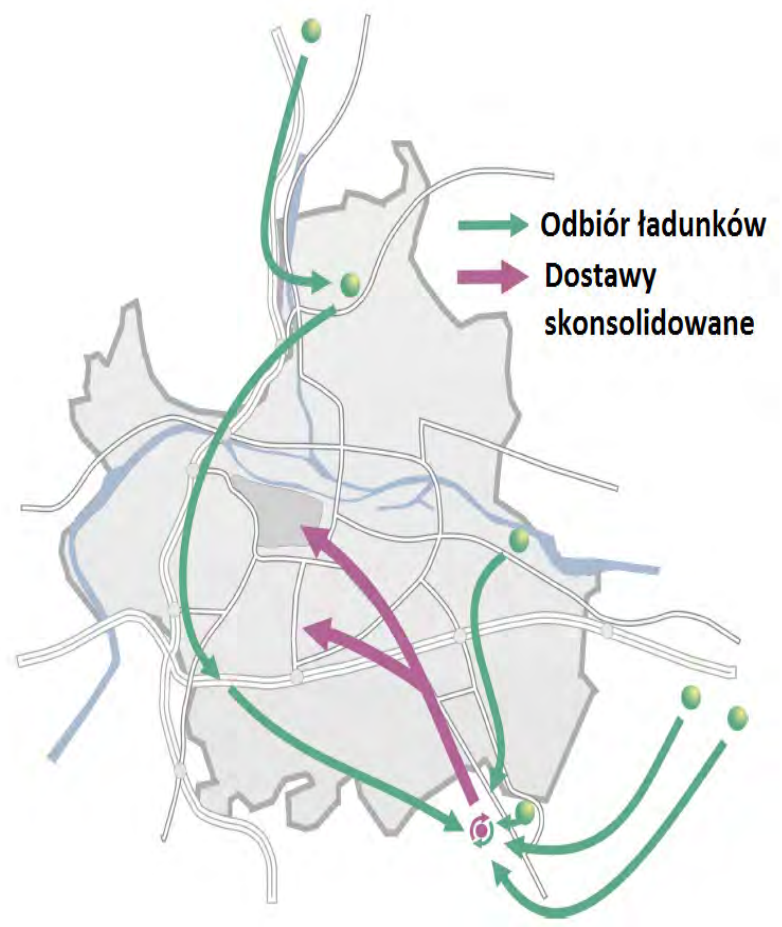

Rysunek 2. Schemat działania projektu RegLog

Źródło: opracowanie własne na podstawie: TRAILBLAZER..., 2010: 6. 
Główną przyczyną powstawania zatorów była bardzo duża liczba dostawców obsługujących tylko część przedsiębiorców. Rozwiązaniem okazała się budowa centrum konsolidacyjnego oraz platformy dla spedytorów, przewoźników, klientów i dostawców pozwalająca na wspólną obsługę dostaw. Koordynacji tych działań podjęła się firma BMW (Kauf, 2010: 42).

Centrum konsolidacyjne (GVZ - Güterverkehrzentrum) zostało wybudowane na południowy wschód od miasta. Towary są odbierane od dostawców i przewożone do centrali, gdzie produkty od różnych dostawców, a przeznaczone dla jednego odbiorcy zostają spaletyzowane. Następnie gotowe palety dla poszczególnych odbiorców są ładowane do jednego samochodu i systematycznie rozwożone (TRAILBLAZER, 2010: 5-6).

Odbiór od dostawców wykonywany jest przez jednego spedytora. Co więcej, pojazdy wykorzystywane są także do odbioru materiałów zużytych, a więc realizowane są również zadania logistyki odwrotnej. Osoby współpracujące w ramach projektu RegLog są zmuszone do przestrzegania ustalonych zasad zgodnie z wymaganiami swoich klientów. Oprócz tego samochody zostały wyposażone w nadajniki GPS, co pozwala śledzić pozycję zamówionego towaru. Dodatkowo zmniejszona liczba samochodów dostawczych znacząco obniża poziom kongestii transportowej, a więc zwiększa się terminowość dostaw (Kauf, 2010: 43). Rysunek 2 przedstawia odbiór oraz dostawy ładunków w ramach projektu RegLog.

Kooperacja dostawców pozwala również na uzyskanie efektu synergii. W ciągu 11 lat realizowania projektu udało się łącznie zmniejszyć przebieg pojazdów o około 55 tys. wozokilometrów, co przekłada się na oszczędności rzędu 12 tys. litrów paliwa. Co więcej, każdego dnia zamiast 25 samochodów ciężarowych do centrum wjeżdża ich tylko 3-4. W ramach logistyki zwrotnej co roku udaje się odzyskać około 1700 ton posegregowanych materiałów przeznaczonych do recyklingu (TRAILBLAZER..., 2010: 7). Rysunek 3 prezentuje efekty wynikające z wprowadzenia kooperacji dostawców oraz konsolidacji ładunków w Ratyzbonie. Oszczędności zarówno czasu, jak i paliwa są wyraźnie zauważalne. Zatem mniejsza liczba samochodów ciężarowych poruszających się po drogach w Ratyzbonie pozytywnie wpłynęła na poziom występującej tam kongestii transportowej.

Ratyzbona jest miastem, które bardzo skutecznie poradziło sobie z redukcją samochodów dostawczych w ścisłym centrum. Ograniczenie to podziałało korzystnie nie tylko na zmniejszenie zatorów panujących na drogach, ale także przyczyniło się do poprawy jakości życia mieszkańców (mniejszy hałas, spadek zanieczyszczenia powietrza czy recykling odpadów). Przykład ten pokazuje, że istnieją rozwiązania pozwalające na utrzymanie wysokiego poziomu zadowolenia zarówno prywatnych przedsiębiorców zamawiających towary, jak też ich dostawców oraz mieszkańców miasta.

Zachodzi ścisły związek między stopniem zintegrowania funkcjonujących rozwiązań a ich skutecznością. Skuteczność wszelkich działań w głównej mierze zależy od współdziałania oraz skupienia ich na celu w sposób zharmonizowany, a także od 
kooperacji poszczególnych elementów różnych systemów. W celu osiągnięcia optymalnych rezultatów niezbędne jest wykorzystanie efektu synergii, gdzie nie tylko liczba i skala wybranych rozwiązań determinuje finalne efekty, lecz przede wszystkim stopień ich współdziałania oraz wykorzystania w sposób zintegrowany.
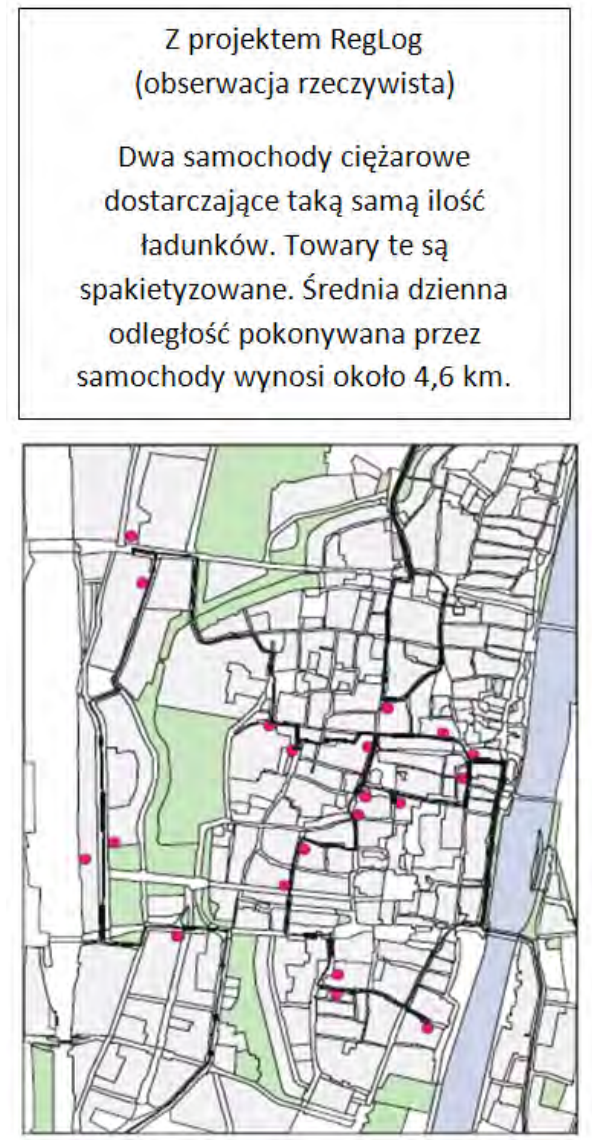
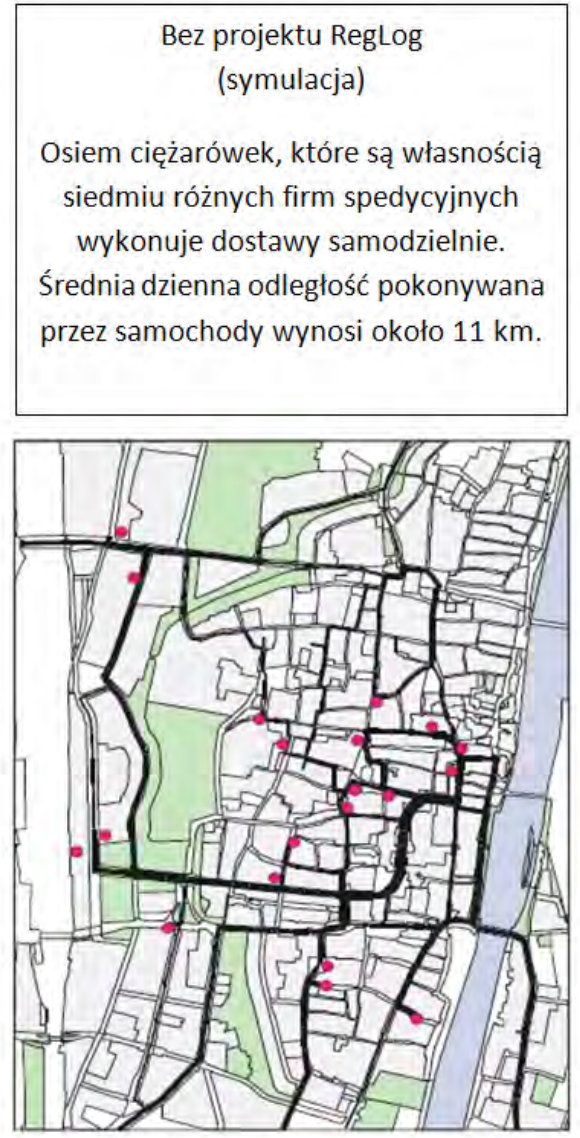

Rysunek 3. Przemieszczenia samochodów dostawczych biorących udział w projekcie RegLog oraz symulacja przemieszczeń pojazdów niebiorących w nim udziału

Źródło: opracowanie własne na podstawie: TRAILBLAZER..., 2010: 8.

Zjawiskiem bardzo pozytywnym jest dająca się ostatnio wyraźnie zaobserwować rosnąca świadomość władz miast oraz ich mieszkańców dotycząca skali i znaczenia problemu kongestii transportowej. Magistraty dużych zespołów miejskich coraz częściej jako zadania priorytetowe wybierają te przyczyniające się do ograniczenia nadmiernego zatłoczenia na drogach. Co więcej, coraz popularniejszy "zielony” styl życia oraz dużo łatwiejszy dostęp do alternatywnych, niejednokrot- 
nie ekologicznych środków transportu (np. rowery miejskie czy pojazdy komunikacji zbiorowej, emitujące znacznie mniej szkodliwych substancji na pasażera w porównaniu z samochodami prywatnymi) znacząco wpływają na zachowania komunikacyjne mieszkańców dużych miast. Coraz wyraźniej widoczna interakcja pomiędzy potrzebami społeczności lokalnych a działaniami władz prawdopodobnie w przyszłości skutkować będzie ograniczeniem liczby samochodów poruszających się po drogach, a co za tym idzie, również zmniejszeniem poziomu panującej na nich kongestii transportowej, hałasu czy ograniczeniem zanieczyszczenia środowiska naturalnego. Praktycznie niemożliwe jest zupełne wyeliminowanie problemu kongestii transportowej występującej na drogach, istnieje jednak duża szansa, że w miarę wdrażania usprawnień w istniejącej polityce transportowej nastąpi znaczne zmniejszenie jej poziomu.

\section{Bibliografia}

Biała Księga Mobilności, (2015), http://transport-publiczny.pl/BKM/BialaKsiegaMobilnosci2015. pdf. [dostęp 12.04.2017].

CIVITAS. Cleaner and better transport in cities, Policy Advice Notes. Promowanie nowej kultury mobilności w miastach, 08, http://www.civitas.eu/sites/default/files/civitas_ii_policy_advice_notes_08_promotion_and_education_pl.pdf [dostęp 12.04.2017].

Deloitte, (2012), Road pricing. Necessity or nirvana?, http://www2.deloitte.com/content/ dam/Deloitte/au/Documents/public-sector/deloitte-au-ps-road-pricing-necessity-nirvana-180914.pdf [dostęp 13.04.2017].

Index of Economic Freedom, (2016), http://www.heritage.org/index/ [dostęp 14.04.2016].

Innovative Demand Management Strategies. Road Pricing Schemes. NICHES, http://www.eltis.org/sites/eltis/files/trainingmaterials/14690_pn13_pricing_ok_low_1.pdf [dostęp 13.04.2017].

Kauf S., (2010), Logistyka jako narzędzie redukcji kongestii transportowej w miastach, „LogForum”, vol. 6, issue 1, number 4, http://www.logforum.net/pdf/6_1_4_10.pdf [dostęp 12.04.2017].

Maćkiewicz J., Co znaczy wyraz „kongestia”, http://fil.ug.edu.pl/strona/15148/znaczy_wyraz_ kongestia [dostęp 11.04.2017].

Menon A. P. G., (2003), Evaluation of Singapore's Electronic Road Pricing (ERP) System, International Symposium on Road Pricing, s. 10-12.

Polityka parkingowa miasta Płock. Wersja 1.0 - konsultacje społeczne, https://www.google.pl/ url?sa=t\&rct=j\&q=\&esrc=s\&source=web\&cd=1\&ved=0ah UKEwiUj9GNwYTLAhXLjiwKHXvq CuUQFggcMAA\&url=http\%3A\%2F\%2Fplock.eu\%2Fajax\%2Cdownload\%2C60.html\%3Fhash\%3Ddcacdffc27fe1fb3b5e35b69020958e0\&usg=AFQjCNH-RIU3mICZ29mOYnllzHOiW0g0-Q\&sig2=zIY3sL6uTyOtH08tLBUOhQ\&cad=rja [dostęp 12.04.2017]. 
Schwab K., (2014), The Global Competitiveness Report 2014-2015, World Economic Forum, Geneva.

Singapur: pół wieku azjatyckiego cudu, (2015), http://www.bankier.pl/wiadomosc/Singapur-pol-wieku-azjatyckiego-cudu-7273078.html [dostęp 14.04.2017].

Stępniak M., (2015), Singapur, czyli pótwieczny mikrogigant, Na Tropie, http://natropie.zhp.pl/ index.php/singapur-czyli-polwieczny-mikrogigant/ [dostęp 13.04.2017].

Szołtysek J., (2011), Kreowanie mobilności mieszkańców miast, Wolters Kluwer Polska, Warszawa.

Thiem J. i in., (2015), Badania powiq̨zań funkcjonalno-przestrzennych w zakresie parkingów dla obszaru aglomeracji poznańskiej. Spójna polityka parkingowa dla obszaru funkcjonalnego aglomeracji poznańskiej. Uwarunkowania. Poznań, http://www.politykaparkingowa.pl/assets/Uploads/POLITYKA-uwarunkowania.pdf [dostęp 12.04.2017].

Tomanek R., (2004), Funkcjonowanie transportu, Wydawnictwo Akademii Ekonomicznej im. Karola Adamieckiego w Katowicach, Katowice.

Traffic congestion improved in Singapore in 2015: Report, (2016), http://www.todayonline.com/ singapore/traffic-congestion-improved-singapore-2015-report [dostęp 13.04.2017].

TRAILBLAZER (Transport And Innovation Logistics by Local Authorities with a Zest for Efficiency and Realization), (2010), Case Study. City logistics in Regensburg, Germany, CPAS.

Wyszomirski O., (2008), Transport miejski - ekonomika i organizacja, Wydawnictwo Uniwersytetu Gdańskiego, Gdańsk.

Zarząd Dróg Miejskich i Komunikacji Publicznej w Bydgoszczy, O bydgoskim systemie ITS, http:// www.zdmikp.bydgoszcz.pl/index.php/pl/inwestycje-i-projekty/2305-o-systemie-its [dostęp 13.04.2017].

Ziemska M., (2014), Cele stosowania inteligentnych systemów transportowych i koordynowania sygnalizacji świetlnej, „Prace Wydziału Nawigacyjnego Akademii Morskiej w Gdyni”, z. 29, Wydawnictwo Akademii Morskiej w Gdyni, Gdynia.

\section{Źródto internetowe}

http://www.ztm.waw.pl/informacje.php?i=157\&c=98\&l=1 [dostęp 13.04.2017]. 